\title{
The stromal vascular fraction mitigates radiation-induced gastrointestinal syndrome in mice
}

\author{
Lydia Bensemmane1, Claire Squiban', Christelle Demarquay ${ }^{1}$, Noëlle Mathieu', Marc Benderitter', \\ Bernard Le Guen ${ }^{2}$, Fabien Milliat ${ }^{1}$ and Christine Linard ${ }^{1 *}$ (i)
}

\begin{abstract}
Background: The intestine is particularly sensitive to moderate-high radiation dose and the development of gastrointestinal syndrome (GIS) leads to the rapid loss of intestinal mucosal integrity, resulting in bacterial infiltration, sepsis that comprise patient survival. There is an urgent need for effective and rapid therapeutic countermeasures. The stromal vascular fraction (SVF) derived from adipose tissue is an easily accessible source of cells with angiogenic, anti-inflammatory and regenerative properties. We studied the therapeutic impact of SVF and its action on the intestinal stem cell compartment.

Methods: Mice exposed to the abdominal radiation (18 Gy) received a single intravenous injection of stromal vascular fraction (SVF) $\left(2.5 \times 10^{6}\right.$ cells), obtained by enzymatic digestion of inguinal fat tissue, on the day of irradiation. Mortality was evaluated as well as intestinal regeneration by histological analyses and absorption function.

Results: The SVF treatment limited the weight loss of the mice and inhibited the intestinal permeability and mortality after abdominal irradiation. Histological analyses showed that SVF treatment stimulated the regeneration of the epithelium by promoting numerous enlarged hyperproliferative zones. SVF restored CD24 $4^{+} / \mathrm{ys}$ szyme $e^{-}$and Paneth cell populations in the ISC compartment with the presence of Paneth $\mathrm{Ki} 7^{+}$cells. SVF has an anti-inflammatory effect by repressing pro-

inflammatory cytokines, increasing M2 macrophages in the ileum and anti-inflammatory monocyte subtypes CD11b ${ }^{+} L y 6 C^{\text {low } C X 3 C R} 1^{\text {high }}$ in the spleen.

Conclusions: Through the pleiotropic effects that contribute to limiting radiation-induced lethality, SVF opens up attractive prospects for the treatment of emergency GIS.
\end{abstract}

Keywords: Stromal vascular fraction, Intestine, Irradiation, Regeneration

\section{Background}

Accidental or intentional exposure to high doses of ionising radiation can have serious health consequences for the exposed persons and can potentially affect many people at the same time. Irradiation of large volumes at medium to high radiation doses has serious effects on normal, fast-renewing tissues, and all these effects are

\footnotetext{
* Correspondence: christine.linard@irsn.fr

${ }^{1}$ Institute of Radiological Protection and Nuclear Safety, Laboratory of Medical Radiobiology, Fontenay-aux-Roses, France

Full list of author information is available at the end of the article
}

grouped together under the acute radiation syndrome (ARS). The speed at which the first symptoms appear depends on the rate of renewal of the cells making up the damaged tissue, but also on the radiosensitivity of the stem cells. The gastrointestinal (GI) tract is particularly sensitive to irradiation and lethality resulting from GI tract failure, which is the primary endpoint of ARS. A dose greater than 10 Gy in total body irradiation (TBI) leads to diarrheoa, dehydration, sepsis and intestinal haemorrhage with mortality within 7-10 days after exposure. 
Normal homeostasis of the intestinal epithelium is maintained by a complex cell replacement process. This renewal is initiated by intestinal stem cells (ISCs), notably the $\operatorname{Lgr} 5^{+}$cells located at the base of the crypts [1]. These stem cells divide, migrate and become Lgr5 progenitors or transit-amplifying progenitor (TA) cells committed to differentiation. Differentiated TA cells generate villi composed of intestinal epithelial cells (IECS). Lgr $5^{+}$cells are flanked on both sides by secretory Paneth cells. In addition to their antimicrobial role, these cells have played an essential niche role in supporting $\operatorname{Lgr}^{+}$cells, both through cell-cell contact and by secreting the factors necessary to maintain the gut stem cell niche [2].

Radiation-induced gastrointestinal syndrome (GIS) is due in part to the destruction of intestinal stem cells (ISCs) in the crypt [3], which are radiosensitive. The crypt becomes "non-viable" and dies out within $48 \mathrm{~h}$. However, one or more surviving ISCs can rapidly proliferate to regenerate the crypt within 72-96 h. Therefore, the repopulation of clonogenic proliferating progenitor cells by the ISCs plays a key role in the fate of the crypt. A damaged intestinal epithelium promotes the influx of bacteria into the bloodstream leading to sepsis and death [4]. Considering the logistical barrier and urgency delay within the first $24 \mathrm{~h}$ after exposure for treatment of the victim, in large casualty settings, there is a concrete need for therapeutic measures that can be effective even if started days after the accidental radiation exposure. Currently, there are very few drugs known to mitigate the effects of radiation. In part of an artificial analogue of flagellin, which has improved gut stem cell survival after whole body irradiation in mice [5] and in a non-human primate [6], it may have mitigating pharmacological treatment potential, but there is no medical countermeasure for gastrointestinal treatment in humans.

Studies have shown that cell therapies restore the niche of intestinal stem cells after irradiation [7] and that mesenchymal stem cell (MSC) administration can improve survival, restore intestinal structure and function and increase epithelial cell proliferation [8-11]. However, the culture time required to amplify enough cells remains an obstacle to their use in the emergency treatment of gastrointestinal syndrome (GIS).

It has been recently demonstrated that adipose tissue can be an important source of cell progenitors, easily accessible and extremely rapid. Adipose tissue-derived stem cells (ASCs) share many properties with bone marrow mesenchymal stem cells. They have the potential to differentiate into multiple cell lineages and have angiogenic, anti-apoptotic, immunomodulatory and regenerative properties [12]. ASCs have self-renewal properties and are localised in the stromal vascular fraction (SVF) obtained from enzymatically digested adipose tissue. SVF constitutes a vascular niche with an important source of endothelial progenitors, endothelial cells and pericytes, thus contributing to vessel remodeling and growth [13]. In addition, SVF contains various immune cells, including monocytes and macrophages that perform anti-inflammatory functions [14]. The mechanisms through which SVF regenerates tissue remain inconclusive, but the literature suggests a contribution by paracrine effects, with crosstalk between SVF components and the host leading to repair and healing [12]. Currently, the therapeutic use of SVF is expanding in some clinical trials of multiple pathologies [12], particularly for refractory Crohn's fistula [15].

In this study, we evaluated the therapeutic efficacy of SVF in a GIS model and examined the impact of SVF on the niche compartment of intestinal stem cells and the impact on the inflammatory process.

\section{Methods \\ Mice}

Male C57BL/6JRj mice were purchased from Janvier (Le Genest Saint Isle, France) and the animals were housed in the IRSN animal facilities, which are accredited by the French Ministry of Agriculture for performing experiments on rodents. The animal experiments were performed in compliance with French and European regulations on the protection of animals used for scientific purposes (EC Directive 2010/63/EU and French Decree 2013-118). All experiments were approved by the Ethics Committee \#81 and authorised by the French Ministry of Research (under the reference APAF IS\#10434-2017062814437026-v1). In this study, the experimental protocol was in line with the standard support treatment recommended for the patient presenting an acute radiation syndrome [16]. Thus, the antibiotic Avemix $(8 \mathrm{~g} / \mathrm{L})$ will be associated with all treatments and during the experimentation.

\section{Irradiation procedure}

Eight-week-old C57BL/6JRj mice were irradiated under anaesthesia (with a continuous flow 1.5\% isoflurane in oxygen) on a medical linear accelerator (Elekta synergy ${ }^{\circ}$ ) delivering 4MVp X-rays (mean photon energy about 1.3 $\mathrm{MeV}$ ). Reference dosimetry measurements were performed using a 0.125 cc cylindrical ionisation chamber calibrated in dose to water in a mouse equivalent tissue phantom placed on a plexiglass support. A dose rate about $2.5 \mathrm{~Gy} / \mathrm{min}$ in dose to water was used. A localised 2-cm larger abdominal irradiation window containing intestine was chosen to limit the upper thorax, head and neck and lower and upper extremity exposure. The mice were exposed to 16, 18, 20 and 22 Gy. The dose of 18 Gy was further selected as the sublethal optimal irradiation dose for SVF-related effects. The uncertainty of the dose rate measurement was about $5 \%$ at $\mathrm{k}=2$. 


\section{Isolation of SVF}

Stromal vascular fraction (SVF) cells were isolated from inguinal fat pad adipose tissue samples of 12-week-old C57BL/6JRj mouse donors. From the modified methods [17], the fat pads were excised, finely cut and incubated in a digestion medium containing $0.1 \%$ type I collagenase (Sigma-Aldrich, France) and 1\% penicillin-streptomycin in MEM- $\alpha$ milieu by gentle shaking for $20 \mathrm{~min}$ at $37^{\circ} \mathrm{C}$. The samples were briefly mechanically disrupted using the gentleMACS Dissociator (Miltenyi Biotec) and then digested again in MEM- $\alpha$ 0.1\% type I collagenase medium followed by mechanical disruption using the gentleMACS Dissociator. To remove mature adipocytes and undigested tissue, the cell suspension was filtered sequentially through 100 - and $70-\mu \mathrm{m}$ cell strainers and centrifuged $(400 g, 10 \mathrm{~min})$ to spin down stromal vascular fraction cell pellets. The pellets were resuspended in phosphatebuffered saline (PBS) for i.v. injection.

\section{Histology \\ Microcolony stem cell assay}

Freshly isolated ileal tissue was excised, flushed with cold phosphate-buffered saline and fixed in $4 \%$ paraformaldehyde and embedded in paraffin. At day 3.5, ileal sections were stained using haematoxylin, eosin and Safran (HES). The sublethal dose was determined by the number of regenerating crypts along the ileum with the presence of $10 \%$ of the crypts by unit of length of intestine containing at least 8-10 cells at day 3.5 after irradiation [18].

\section{Immunohistochemical analysis}

Sections $5 \mu \mathrm{m}$ in thickness were de-paraffinised and rehydrated. A pretreatment method using heat-induced epitope retrieval was used, and the nonspecific binding was blocked with a protein blocker (DakoCytomation, Trappe, France) for $30 \mathrm{~min}$ at room temperature (RT). The sections were then incubated with the following primary antibodies against Ki67 (ab15580; Abcam), EpCam (clone G8.8; Biolegend), $\alpha$-SMA (ab21027; Abcam), CD34 (RAM34, eBioscience), GP38 (MA615113; Thermo Fisher), CD24 (ab64064; Abcam), Lysozyme (ab108508; Abcam), Muc2 (Thermo Fisher) and ZO-1 (Invitrogen) antibodies.

The co-labelling with antibodies from the same species was performed using Opal ${ }^{\mathrm{m}}$ Multiplex IHC kits (Akoya). After incubation with the primary antibodies, the slides were washed in PBS-T three times and probed with appropriated fluorescence-conjugated secondary antibodies for $1 \mathrm{~h}$ at room temperature. After three washings in PBS, the cell nuclei were counterstained by Vectashield mounting medium with DAPI (Vector).

\section{TUNEL assay}

A TUNEL assay was performed using an In Situ Cell Death Detection Kit (Roche Diagnostics, France) following the manufacturer's instructions. Intestinal tissue sections were incubated with a reaction mixture of terminal deoxynucleotidyl transferase (TdT) and fluorescein (FITC)-labelled precursor in a cacodylate-based buffer for $1 \mathrm{~h}$ at $37{ }^{\circ} \mathrm{C}$, then rinsed three times with $0.05 \%$ Tween-20 in PBS and mounted under Vectashield mounting medium with DAPI (Vector). The apoptotic rate in the crypts and villis cells was quantified by counting the number of apoptotic cells per unit area of the section.

\section{Intestinal permeability in vivo}

In vivo intestinal permeability measurement was assessed at 7 days following irradiation, using $4000 \mathrm{Da}$ FITC-dextran (Sigma-Aldrich, France). In short, FITCdextran $(0.60 \mathrm{mg} / \mathrm{g}$ body weight $)$ was administrated by gavage and $4 \mathrm{~h}$ after the mice were euthanised and plasma obtained by cardiac puncture. Standard curves were obtained by diluting the FITC-dextran in the PBSdiluted plasma to determine the serum levels of FITCdextran in the different treatment groups. The FITC concentration in the plasma was then measured with a microplate Luminometer (Mithras LB940, Berthold) at an excitation wavelength of $485 \mathrm{~nm}$ and an emission wavelength of $520 \mathrm{~nm}$.

\section{Splenic cell isolation}

To isolate the splenic cells, the spleen was smashed with a syringe plunger and the cells were collected in PBS buffer followed by passage through $40-\mu \mathrm{m}$ cell strainers and centrifuged $(400 \times g, 10 \mathrm{~min})$. The red blood cells were lysed with ACK lysis buffer (Thermo Fisher Scientific, France).

\section{Flow cytometric analysis}

Flow cytometry was performed using the BD FACS Canto II and analysed with FlowJo software (Tree Star, Ashland, OR). Dead cells were excluded through Fixable Viability Dye eFluor staining (eBioscience). Nonspecific antibody binding was blocked with an anti-CD16/32 (Mouse Fcy block clone 2.4G2). The cells were incubated for $30 \mathrm{~min}$ in $100 \mu \mathrm{l}$ PBS with conjugated antibodies (BD Biosciences, France): anti CD45 (V500 conjugated; clone 30-F11), CD11b (BV421 conjugated; clone M1/70), anti CD3 (FITC conjugated; clone 1452C11), anti CD45R/B220 (PE-Cy7 conjugated; clone RA3-6B2), anti Ly6C (FITC conjugated; clone AL-21), anti CD31 (PE conjugated; clone MEC13.3), anti CD34 (Alexa Fluor 647 conjugated; clone RAM34), anti CD146 (FITC conjugated; clone ME-9F1), anti CD29 (PE conjugated; clone HM B1.1), anti Sca-1 (PE-Cy7 conjugated; clone D7), anti CD44 (PE-Cy5.5 conjugated; clone IM7), anti CD105 (Alexa Fluor 647 conjugated; clone MJ7/18), anti SSEA (BV421 conjugated; clone MC631), anti 
CX3CR1 from Biolegend (France) (PE-Cy7 conjugated; clone SA011F11), anti CCR2 (Alexa Fluor 647 conjugated; clone SA203G11) and CD90 from southern Biotech (FITC conjugated; clone SA203G11). Isotypematched antibodies (BD Biosciences) were used for control staining. All antibodies were used at 1:100 dilution. The concentration of cell suspensions was adjusted to 1 $\times 10^{6}$ cells per $100 \mu$ l.

\section{Spreading assay and immunostaining}

Spleen mononuclear cells MNCs isolated from all the experimental groups were resuspended in RPMI 1640 medium containing $10 \% \mathrm{FBS}$ and $1 \%$ penicillin/streptomycin and seeded on round 12-mm diameter coverslips in a 24-well plate coated with $5 \mu \mathrm{g} / \mathrm{ml}$ recombinant mouse VCAM-1 (R\&D Systems) for $2 \mathrm{~h}$ at $37^{\circ} \mathrm{C}$. After two washes with PBS, the cells were fixed with $4 \%$ paraformaldehyde for $10 \mathrm{~min}$ at $+4^{\circ} \mathrm{C}$. The cells were rinsed three times with PBS and then incubated in PBS/0.1\% Triton X-100 (Sigma-Aldrich) for $10 \mathrm{~min}$. After three rinses with PBS and incubation with $2 \%$ BSA to block nonspecific staining, the cells were stained with $0.165 \mu \mathrm{M}$ Alexa Fluor 546 Phalloidin (Thermo Fisher Scientific, France) for $60 \mathrm{~min}$ at $37^{\circ} \mathrm{C}$. The primary antibody anti-CX3CR1 (Abcam) was used for immunostaining. After the incubation, slides were washed with PBS$\mathrm{T}$ and probed with fluorescence-conjugated secondary antibodies for $1 \mathrm{~h}$ at RT. The cell nuclei were counterstained by Vectashield mounting medium with DAPI (Vector). Cells with flat morphology or lamellipodia were positively scored for spreading.

\section{Monocyte/macrophage polarisation}

The spleen cells were washed three times and cultured in a 12-well tissue culture in RPMI-1640 supplemented with $10 \%$ FBS and antibiotics (penicillin/streptomycin, Invitrogen) and $100 \mathrm{ng} / \mathrm{ml}$ of M-CSF (R\&D Systems, France) at $37^{\circ} \mathrm{C}$ in a humidified atmosphere containing $5 \% \mathrm{CO}_{2}$ for 7 days to induce full macrophage differentiation and maturation. Macrophage polarisation was obtained by removing the culture medium and culturing cells for an additional $24 \mathrm{~h}$ in RPMI-1640 supplemented with 10\% FBS and antibiotics and $100 \mathrm{ng} / \mathrm{ml}$ LPS (derived from E. coli 0111:B4, Invivogen) plus $20 \mathrm{ng} / \mathrm{ml} \mathrm{IFN- \gamma} \mathrm{(for} \mathrm{M1} \mathrm{polarisation,}$ $\mathrm{M}(\mathrm{LPS}-\mathrm{IFN}-\gamma)$ ) or $20 \mathrm{ng} / \mathrm{ml} \mathrm{IL-4}$ (for M2 polarisation, M(IL-4)) (R\&D Systems). The cells were harvested for RT-qPCR analysis.

\section{Real-time PCR analysis}

Total RNA was extracted from the ileum and spleen cells with the RNeasy Mini kit (Qiagen), and cDNA was prepared with the SuperScript RT Reagent Kit (Applied Biosystems). Real-time PCR was performed on an ABI Prism 7900 Sequence Detection System. All Taqman primers and probes came from Life Technologies (France) (Supplemental table). The data were analysed using the $2^{-\Delta \Delta \mathrm{Ct}}$ method, with normalisation to the $\mathrm{Ct}$ of the glyceraldehyde 3-phosphate dehydrogenase (GAPDH) housekeeping gene.

\section{Statistics}

The data are expressed as the mean \pm SEM. We used one-way or two-way analyses of variance (ANOVA) and then a Bonferroni post-test to determine the significance of the differences. $p$ values less than 0.05 were considered statistically significant.

\section{Results \\ Characteristics of radiation-induced GIS after abdominal irradiation}

In order to limit bone marrow exposure, abdominal irradiation was performed [19]. The current standard endpoint for the study of acute GIS is animal lethality within 10 days of radiation exposure (LD50/10) (LD: lethal dose for $50 \%$ at 10 days). In this way, to define the sublethal dose, we administered an increasing dose up to 16 to 22 Gy to obtain a GIS characterised by a strong and rapid weight loss and death between 7 and 10 days. Exposure to 16, 18, 20 and 22 Gy was lethal in 0, 70, 75 and $100 \%$ of the mice within 14 days with a DLO/10, DL65/10, DL75/10 and DL100/10, respectively (Fig. 1a). Lethality was strongly correlated with weight loss, with about a 30\% loss observed 7 days after irradiation in groups of animals irradiated at 18 and 20 Gy (Fig. 1b). The dose that induces a GIS was established on the basis of the number of regenerating crypts forming microcolonies 3.5 days after irradiation. It is a marker of intestinal integrity objectified by the presence of $10 \%$ of crypts per intestinal section with at least 8-10 cells per crypts and is correlated with survival. This time corresponds to the maximum expected difference between restoration and loss of crypts/villi. At day 3.5, histological analysis (HES) showed a change in tissue architecture observed from the 18-Gy dose with drastic reductions in villi length, hypoplasia of crypts and destruction of epithelial architecture (Fig. 1c). The analysis of the density of regenerating intestinal crypts was $66,17,8$ and $1 \%$ at doses of 16 , 18,20 and $22 \mathrm{~Gy}$, respectively, compared with nonirradiated mice (Fig. 1d). In parallel, representative images of TUNEL-positive cells characterising the irreversible cell death showed an increase in the frequency of TUNEL-positive cells in the mucosa with an escalating dose from 16 to 22 Gy compared with non-irradiated mice (Fig. 1e). Taken together, from the results of survival experiments and the histological analysis, a dose of 18 Gy was the sublethal dose inducing a GIS. 


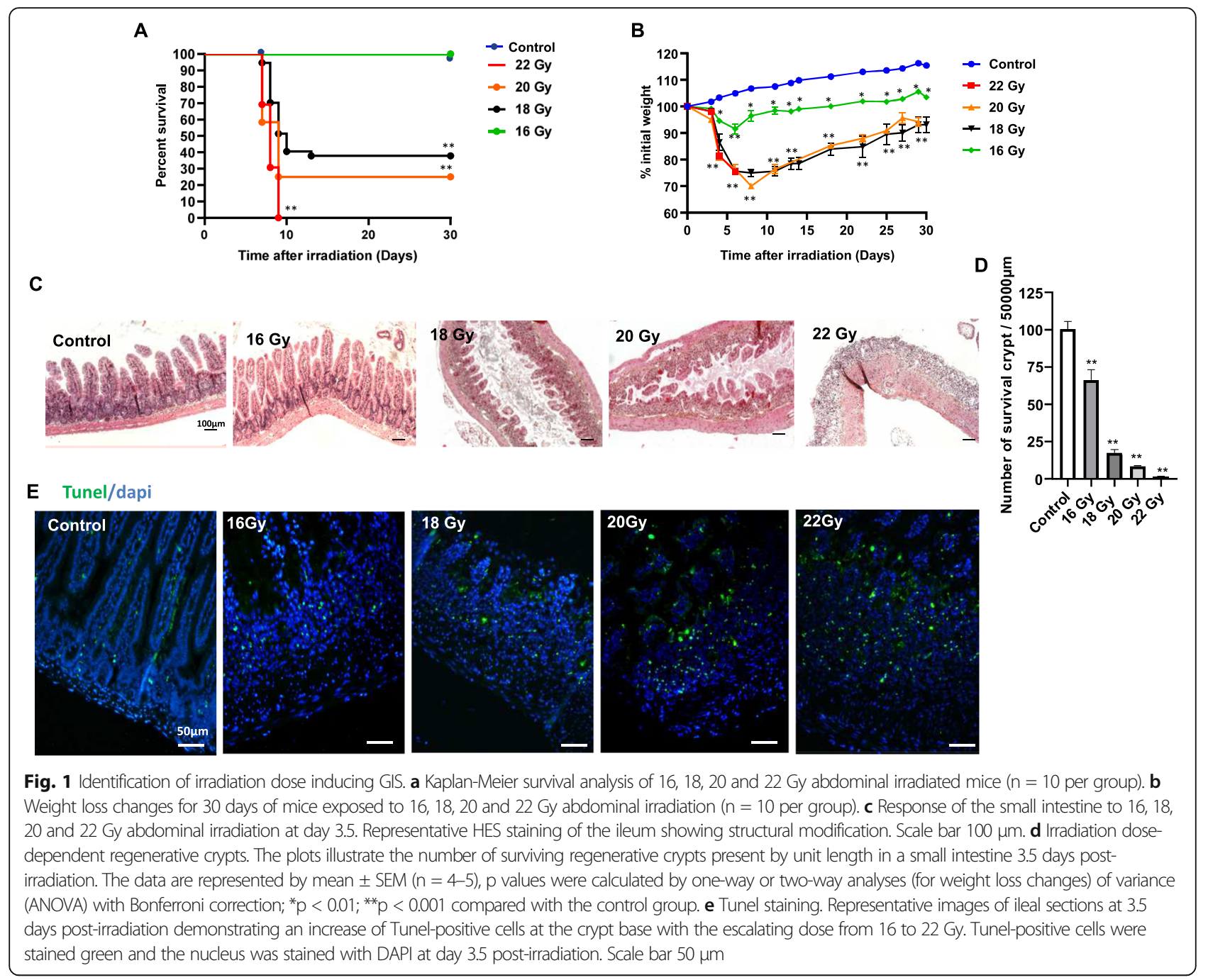

\section{SVF improves survival following a sublethal dose of irradiation and mitigates GIS}

SVF was prepared from animal donors and characterised by flow cytometry. The gating strategy and subpopulation determination are shown in supplemental figure (S1). The viability of cells was $>95 \%$. Expression of mesenchymal, vascular, pericytic and haematopoietic markers as well their combinations showed that the percentage of the mesenchymal marker was $>60 \%$ for CD90, CD44 and CD29; $>50 \%$ for Sca- 1 ; and $>10 \%$ for CD105 and $0.3 \%$ for SSEA3. The SVF also contained haematopoietic cells with $>60 \% \quad \mathrm{CD} 45^{+} \mathrm{CD}^{+}, \quad 2 \%$ $\mathrm{CD}_{4} 5^{+} \mathrm{CD} 11 \mathrm{~b}^{+}$and $>20 \% \mathrm{CD} 5^{+} \mathrm{CD} 11 \mathrm{~b}^{-} \mathrm{B} 220^{+}$. Interestingly, SVF also contained a small amount $(<1 \%)$ of endothelial mature cell $\left(\mathrm{CD} 31^{+} \mathrm{CD} 34^{-} \mathrm{CD} 146^{+}\right)$and endothelial progenitor $\left(\mathrm{CD} 31^{+} \mathrm{CD} 34^{+} \mathrm{CD} 146^{+}\right)$.

Weight loss monitoring was first used to establish the concentration of SVF cells to be injected. At a concentration of $0.5 \times 10^{6}$, SVF cells had no effect on weight loss on day 7 (about 25\%) compared with the irradiated group. Seven days after irradiation, a loss of only $10 \%$ was observed in the groups of animals injected with 1 and $2.5 \times 10^{6}$ (Fig. 2a). The SVF concentration of $2.5 \times$ $10^{6}$ cells will be injected in future experiments. Treatment with SVF of $2.5 \times 10^{6}$ cells limits weight loss and allows them to regain weight faster than the irradiated mice (Fig. 2b). In terms of mortality, while $65 \%$ of the untreated-irradiated mice died within 10 days, the SVF treatment saved $80 \%$ of mice from lethality (Fig. 2c).

High irradiation doses induce apoptosis of the crypt epithelial cells, resulting in a decrease in regenerating crypt colonies at 3.5 days and ultimately villi denudation by day 7 post-irradiation. The number of regenerative crypts microcolonies 3.5 days after irradiation was significantly increased in mice treated with SVF $(44.5 \pm$ $5.3 / \mu \mathrm{m} ; \mathrm{p}<0.001)$ compared with the irradiated mice $(17.5 \pm 2.2 / \mu \mathrm{m})$ (Fig. $2 \mathrm{~d})$, indicating an intestinal regenerative response. Moreover, mice treated with SVF had a significant decrease in the number of $\mathrm{Tunel}^{+}$cells (5fold; $\mathrm{p}<0.001$ ), especially near the position of the crypt 


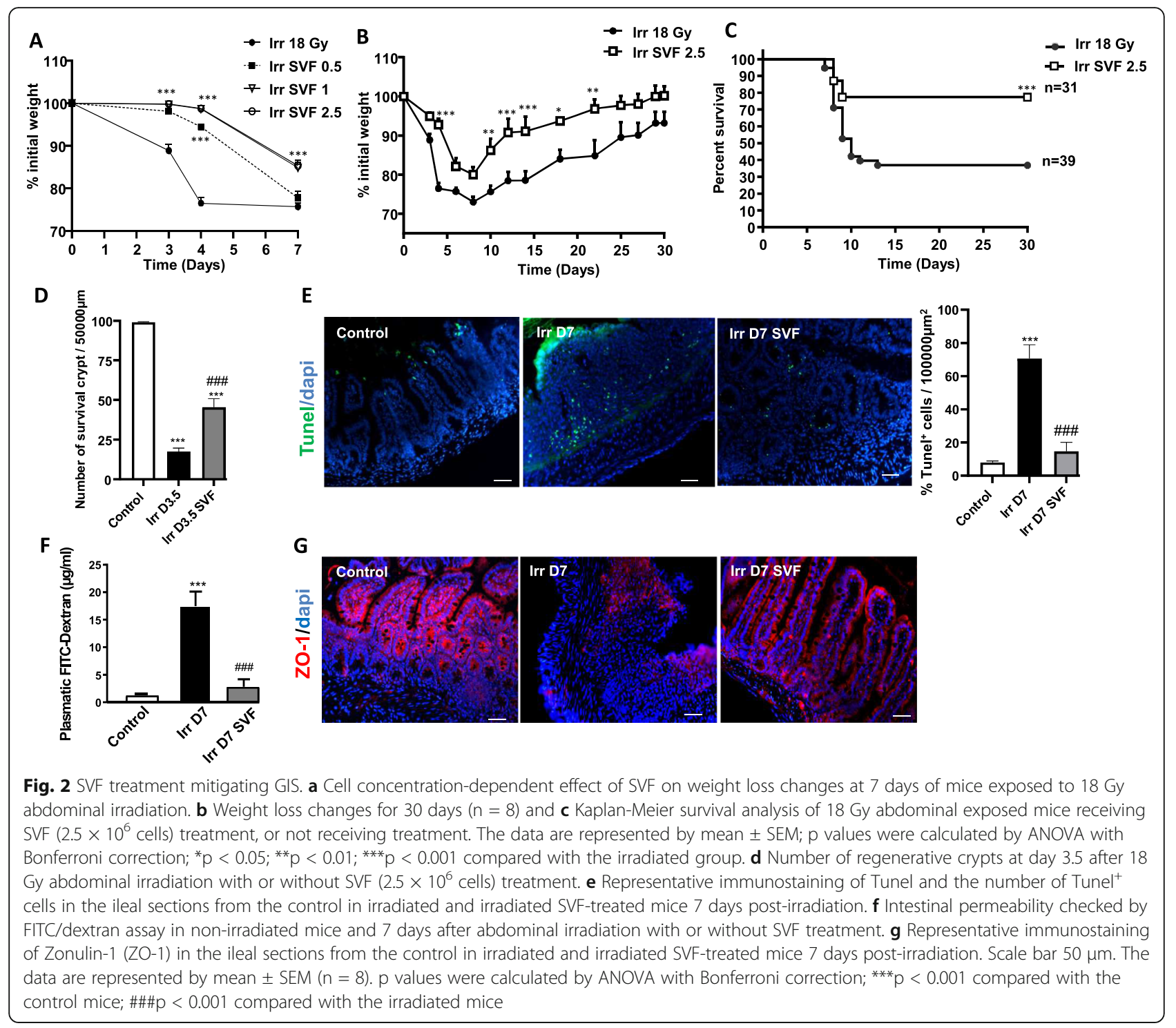

cells 7 days after irradiation, compared with irradiated mice; the number and the localisation (far away from the crypt cells) of Tunel ${ }^{+}$cells were similar to the nonirradiated mice (Fig. 2e).

Disruption of the intestine structural integrity alters its barrier function, making it permeable to luminal content. Dextran is unable to cross the intestinal epithelium when it is intact [20]. Intestinal permeability was quantified 7 days after irradiation with FITC-labelled dextran in the blood $4 \mathrm{~h}$ after gavage. Abdominal irradiation significantly increased intestinal permeability $(17.5 \pm 2.6 \mu \mathrm{g} /$ $\mathrm{ml}$ versus $1.4 \pm 0.1 \mu \mathrm{g} / \mathrm{ml}$ for the control; $\mathrm{p}<0.001)$. Treatment with SVF restores the impermeability (3.2 \pm $1.5 \mu \mathrm{g} / \mathrm{ml}$ ) compared to the non-irradiated mice (Fig. 2f). The permeability was characterised by tight junction loss. Indeed, immunostaining of the tight junction protein zonula occludens- 1 ( $\mathrm{ZO}-1$ ) showed that $\mathrm{ZO}-1$ in the control group was expressed in the cytomembrane of epithelial cells along the villi. Seven days postirradiation, the expression of $\mathrm{ZO}-1$ was considerably reduced when SVF treatment restored its expression (Fig. 2g). These results indicate that SVF treatment induced a functional restoration of intestinal epithelial integrity.

\section{SVF increases intestinal regeneration}

The maintenance of the epithelial barrier is also mediated by epithelial cell adhesion molecules such as EpCam, which also plays a role in cell proliferation, migration and differentiation [21]. In non-irradiated mice, EpCam expression is observed at the crypts and villi and localised on the plasma membrane. Seven days after irradiation, a decrease in EpCam expression was observed as well as a disturbance in its localisation, with a 
mislocalisation in cytoplasm (Fig. 3a). SVF treatment is associated with a recovery of EpCam expression both in the stem cell compartment and on the surface of the mucosa.

Decreased EpCam expression may also impact stem cell proliferation/differentiation [21]. In the control group, Ki-67 immunostaining showed that the majority of proliferating cells were located in the transient amplification cell compartment and did not reside in the base of the crypt. Irradiation leads to a decrease in the number of $\mathrm{Ki}-67^{+}$cells in the ISC compartment. SVF treatment results in a significant increase in the number of Ki-67-positive cells in the ISC compartment, the transient amplification cell compartment and the extending regenerative epithelium, resulting in an enlarged and expanded hyperproliferative cluster area (Fig. 3b).

Mesenchymal-derived factors are essential for maintaining intestinal epithelial stem cell homeostasis. In particular, the double-positive stromal cells $\mathrm{Gp} 38^{+} \mathrm{CD} 34^{+}$ in the pericryptal localisation implicated in the production of niche factors are localised near the crypts in close contact with $\mathrm{Lgr} 5^{+}$stem cells [22]. The double immunostaining Gp38/CD34 showed that irradiation negatively impacts these stromal niches 7 days after irradiation and that the treatment by SVF enables them to be restored (Fig. 3c).

\section{SVF stimulates the restoration of the IECS}

CD24 is a marker of the lower crypt IECS [23] and therefore used to identify LGR $5^{+}$and Paneth cells. In non-irradiated mice, we observed the presence of 2.5 $\mathrm{CD}_{24}{ }^{+}$lysozyme ${ }^{-}$cells per crypt, the corner-shaped cell population between Paneth cells (Fig. 4a). An $80 \%$ loss of these cells was observed at day 7 after irradiation and SVF treatment restored this cell population. Paneth cells contribute to intestinal homeostasis by synthesising

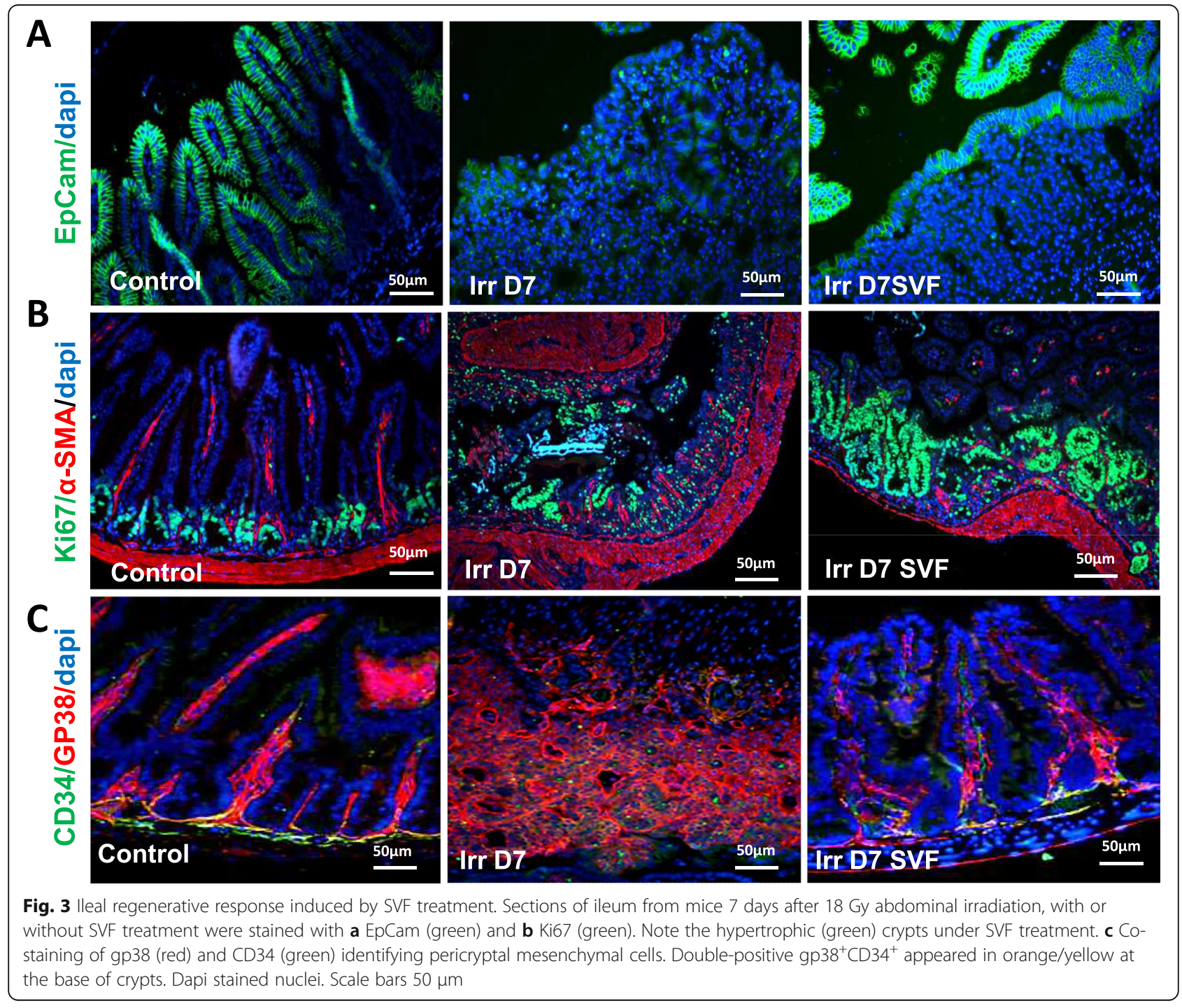




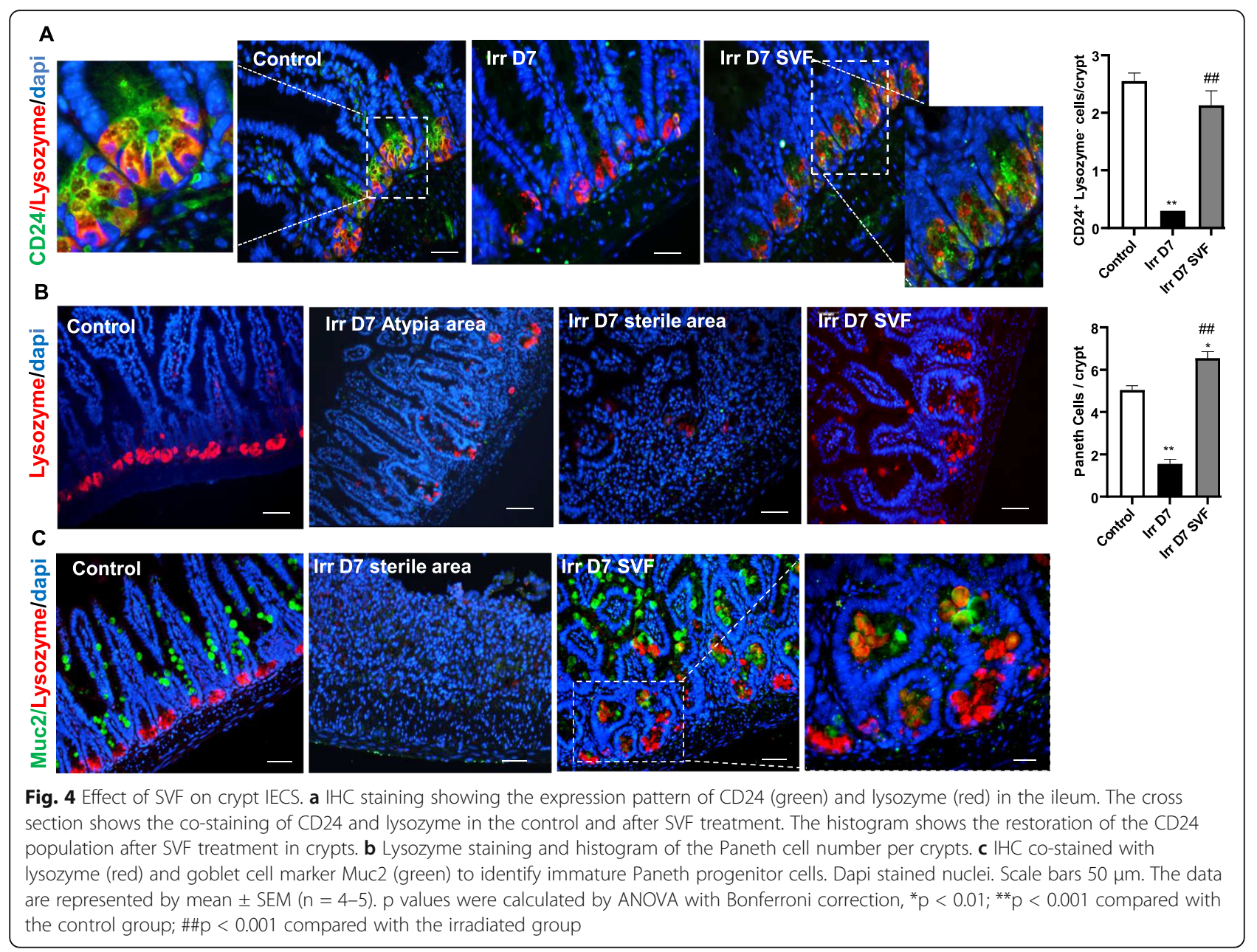

peptides and antimicrobial proteins such as lysozyme and stem cell niche factors [2] and further promoting crypt base formation [24]. By using lysozyme staining to identify Paneth cells, we observed that the number of lysozyme $^{+}$cells decreased significantly on day 7 after irradiation $(\mathrm{p}<0.001)$ compared with the control mice (Fig. 4b). In the control mice, the lysozyme was normally efficiently packaged in well-defined secretory granules in the Paneth cells. In the irradiated mice, the Paneth cells exhibited altered lysozyme allocation patterns, with the majority showing reduced (lowly granular) or diffuse lysozyme staining. After SVF treatment, the number of Paneth cells per crypt increased compared with the irradiated mice $(p<0.001)$, which was also higher than in the control mice. Interestingly, we also observed that the number of lysozyme ${ }^{+}$cells in the "upper crypt" increased in mice treated with SVF, suggesting an aberrant ISC niche architecture. The co-localisation of MUC2 (goblet cell marker) and lysozyme (Paneth cell marker) staining characterised an "intermediate" goblet/Paneth cells and were definited as immature or bipotential progenitor cells [25]. Double immunostaining showed that the presence of Paneth cells at the "upper crypt" was costaining with Muc2 after SVF treatment, indicating the presence of the "intermediate" cells (Fig. 4c). To assess whether the observed proliferative cluster was related to IECS, we performed a Ki67/CD24 co-staining. In the control mice, rare $\mathrm{Ki} 67^{+} / \mathrm{CD} 24^{+}$cells were present in the crypts, with the majority of proliferating cells being located in the transit amplification compartment (TA) and not in the base of the crypt (Fig. 5a). On the other hand, in the proliferative cluster induced by SVF treatment, the $\mathrm{CD} 24^{+}$cells were $\mathrm{Ki}^{+} 7^{+}$; an expansion of the TA zone was also observed. In addition, to determine which population was responsible for increased crypt cell numbers, a double Ki67/lysozyme staining was carried out and showed the presence of $\mathrm{Ki} 67^{+} /$lysozyme $^{-}$and $\mathrm{Ki} 67^{+} /$ lysozyme $^{+}$cells 7 days after irradiation in the irradiated mice treated with SVF (Fig. 5b), indicating the proliferation of ISC and in particular the Paneth cells. It has recently been reported that hyperproliferative crypts show a high expression of HSP60, the mitochondrial molecular chaperone involved in the control of ISC homeostasis, and that HSP60-deficient crypts display a loss of 


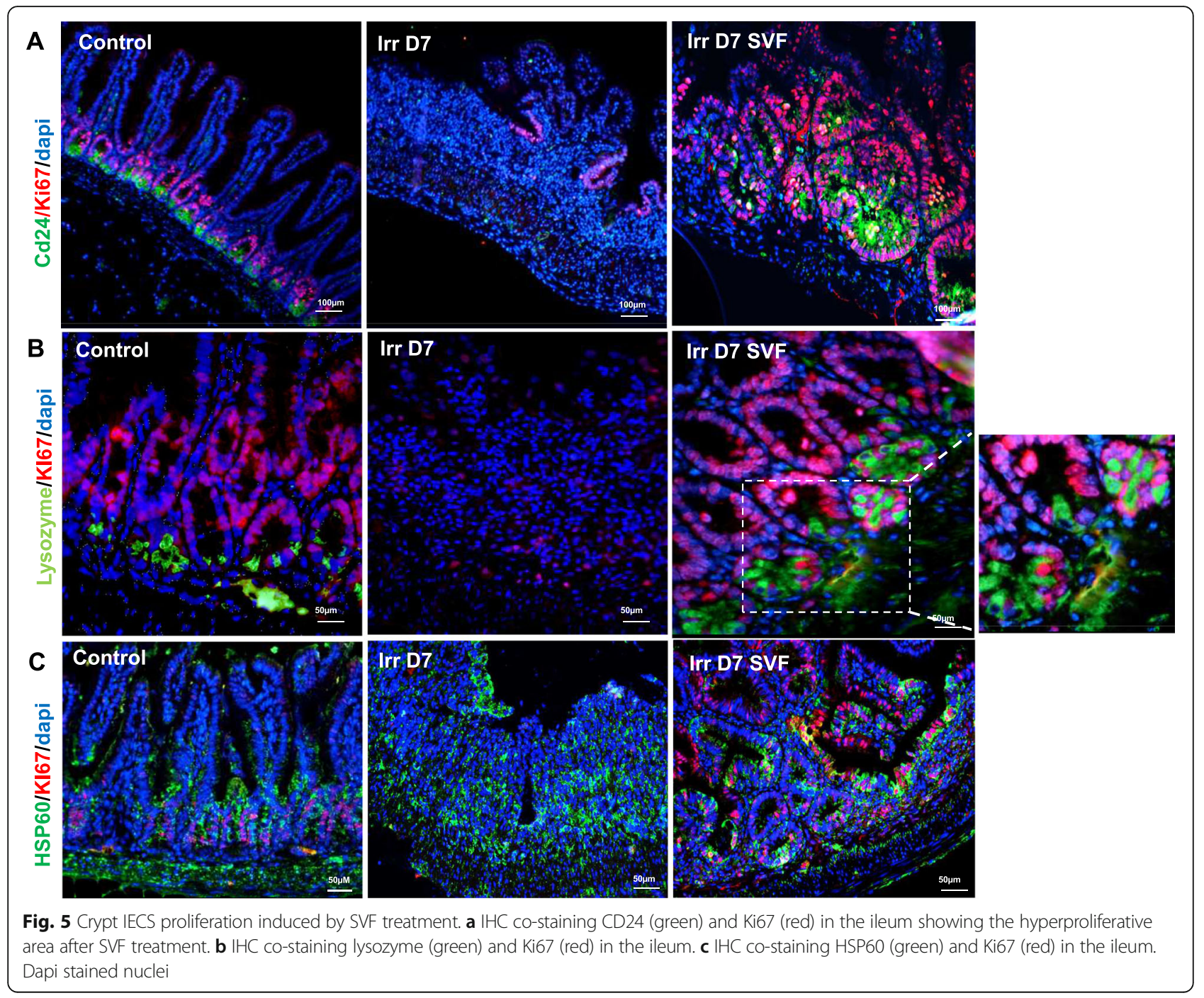

stemness and cell proliferation, resulting in an aberrant Paneth cell phenotype [26]. Here, we observed an increase in the $\mathrm{HSP}^{+}{ }^{+}$cells in the regeneration zone after treatment of SVF (Fig. 5c), indicating the absence of mitochondrial impairment. Together, these results showed that treatment with SVF restored the $\mathrm{CD}_{24}{ }^{+} /$lysozyme $^{-}$and Paneth cell populations and increased the proliferation of the TA compartment $\left(\mathrm{Ki}^{+} 7^{+} / \mathrm{CD} 24^{+}\right)$as well as the proliferation of Paneth cells (lysosyme ${ }^{+} / \mathrm{Ki} 67^{+}$).

\section{SVF limits the inflammatory process by shifting the monocyte-macrophage phenotype}

Macrophages have a central role in the epithelial barrier and in the maintenance of mucosal homeostasis. The spleen is the source of the main subsets of macrophagegenerating monocytes $[27,28]$, and we therefore evaluated the percentage of pro-inflammatory and antiinflammatory monocytes in the spleen 7 days after irradiation and the impact of SVF treatment on the subsets of splenic monocytes. Firstly, the migration potential of splenic monocytes was assessed using the spreading assay performed on a rmVCAM-1 matrix at day 7 after irradiation with and without SVF treatment. Unspread cells were defined as round cells, while spread cells were defined as cells with extended pseudopodia. The percentage of cells adopting the spreading morphology was quantified using fluorescein-conjugated phalloidin, which binds to filamentous actin (Fig. 6a). In the nonirradiated mice, actin filament staining was weak in the splenic monocytes and significantly increased in the irradiated mice (2.7-fold compared with the control; $\mathrm{p}<$ 0.001). Treatment with SVF significantly reduced the intensity of phalloidin staining to $42 \%$ compared with the irradiated mice. This is associated with morphological changes characterised by a normalisation of cell diameter, suggesting an impact on the pro-inflammatory phenotype of these cells [29]. Flow cytometry analysis of 


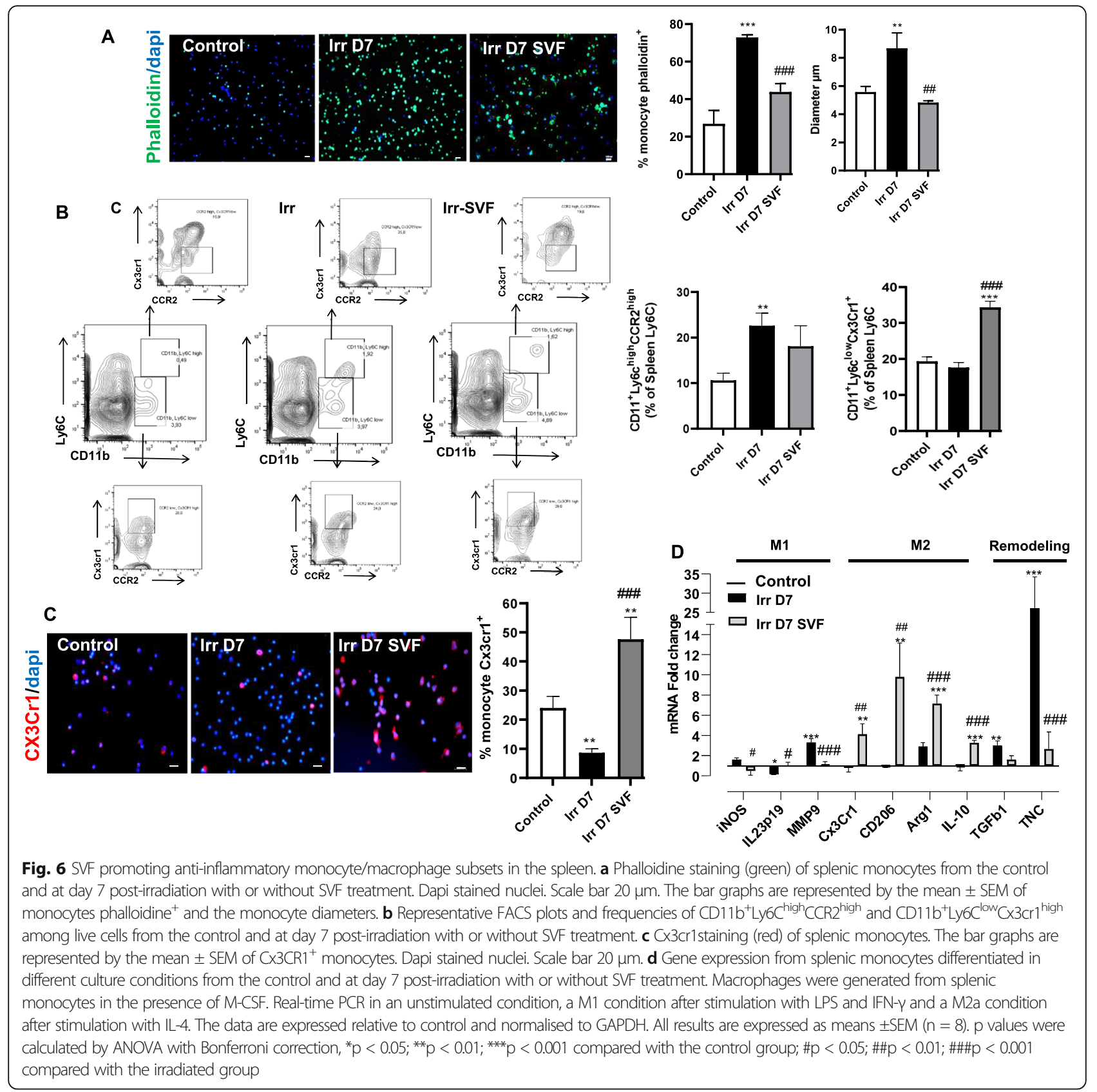

pro-inflammatory and anti-inflammatory monocytes subsets showed a 2.5 -fold $(\mathrm{p}<0.01)$ increase in the percentage of Ly6c $\mathrm{c}^{\text {high }}$ pro-inflammatory monocytes defined

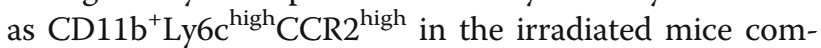
pared with the control mice (Fig. 6b). Treatment with SVF did not reduce the percentage of Ly $6 c^{\text {high }}$ monocytes. On the contrary, the anti-inflammatory monocytes subset $\mathrm{CD} 11 \mathrm{~b}^{+} \mathrm{Ly} 6 \mathrm{c}^{\text {low }} \mathrm{CX} 3 \mathrm{CR} 1^{\text {high }}$ of mice treated with SVF showed a 2 -fold $(\mathrm{p}<0.001)$ higher percentage of anti-inflammatory Ly6 $\mathrm{c}^{\text {low }}$ monocytes than the irradiated mice, which was confirmed by CX3CR1 immunostaining of the splenic monocytes $(\mathrm{p}<0.001)$ (Fig. 6c). In addition, the splenic monocytes could differentiate into proinflammatory M1 or anti-inflammatory M2 macrophages and contribute to tissue repair [30]. To address this issue, macrophages generated by 7 days of culture with M-CSF were stimulated with LPS-IFNY (M1 conversion) or IL-4 (M2 conversion) and the level of mRNA associated with macrophage polarity was analysed by real-time PCR. Our results showed that irradiation stimulated the expression of genes linked to the M1 marker (i.e., iNos, MMP9) without any effect on the expression of genes linked to the M2 marker (Fig. 6d). SVF treatment, on the other hand, reduced the mRNA levels of M1 (iNos, 
MMP9) markers and increased the mRNA levels of M2 markers (CX3CR1, CD206, Arg1, IL-10). Interestingly, the SVF treatment limited the levels of mRNA coding for excessive remodeling markers such as TGF- $\beta 1$ or TNC.

In the ileum, the double CD68/CD206 staining showed the absence of $\mathrm{CD} 206^{+}$cells in the irradiated mice and the SVF treatment led to an increase in $\mathrm{CD}^{+} 8^{+} / \mathrm{CD} 206^{+}$ cells (Fig. 7a). This anti-inflammatory effect in the intestine by the SVF treatment is supported by real-time PCR results with a significant suppression of mRNA levels coding for IL1-1 $\beta$ and IL- 6 compared with the irradiated mice $(\mathrm{p}<0.001)$ (Fig. 7b). Taken together, these results suggest that SVF treatment changes the polarity of monocyte/macrophage to an anti-inflammatory phenotype, which may contribute to improving the GIS.

\section{Discussion}

In the event of accidental or intentional exposure to high doses of radiation resulting in GI syndrome in many victims, there is an urgent need to implement effective and rapid therapeutic countermeasures. SVF can be produced within a few hours, injected on the same day and injected in an autologous way. In our study, we showed that intravenous injection of SVF limited the weight loss of the mice exposed to sublethal irradiation, inhibited the intestinal permeability which resulted in increased survival against lethal doses of radiation. Histological analyses showed that SVF treatment stimulated the regeneration of the epithelium by promoting numerous enlarged hyperproliferative zones and restored the cell populations in the ISC compartment. The therapeutic efficiency was associated to an anti-inflammatory effect.
Potential countermeasures to attenuate GIS have been identified by their ability to improve acute survival in mice (LD50/10) and to increase survival times at LD80/ 10 by at least $50 \%$ [19]. In our study, the therapeutic effect was very important in terms of mortality, with an $80 \%$ mortality in the irradiated and treated animals, compared to $38 \%$ in the untreated-irradiated animals. In addition to the practical advantages of obtaining SVF easily and quickly, the other advantage is its composition that is rich in different cell lineages, which are potentially pro-regenerating and therefore have more pleiotropic effects than MSCs [8-11, 31]. Indeed, previous studies have shown that the injection of MSC into irradiated mice resulted in improved regeneration of intestinal or colonic tissue, increasing the survival of the animals and reducing colonic ulcerations [10, 31]. The effectiveness of MSCs is due to the production of growth factors with anti-inflammatory and pro-angiogenic effects. The supportive effect of MSCs in the regeneration of the intestinal epithelium is not specific to this subpopulation of cells. However, in vitro amplification before their injection limits their use in clinic emergencies. Other cell types are involved in the regenerative response to irradiation such as endothelial cells and immune cells [32]. In our study, the characterisation of SVF in mice showed a high proportion of both MSCs and immune cells and the presence of endothelial progenitors. The combined presence of these different cell types seems to be responsible for the superiority of efficacy compared to the treatment of MSCs alone [33].

The mechanism of the therapeutic efficiency of SVF remains poorly understood. The literature supports the contribution of paracrine effects, with crosstalk between SVF components and the host, leading to repair and healing [12]. In our model, the SVF
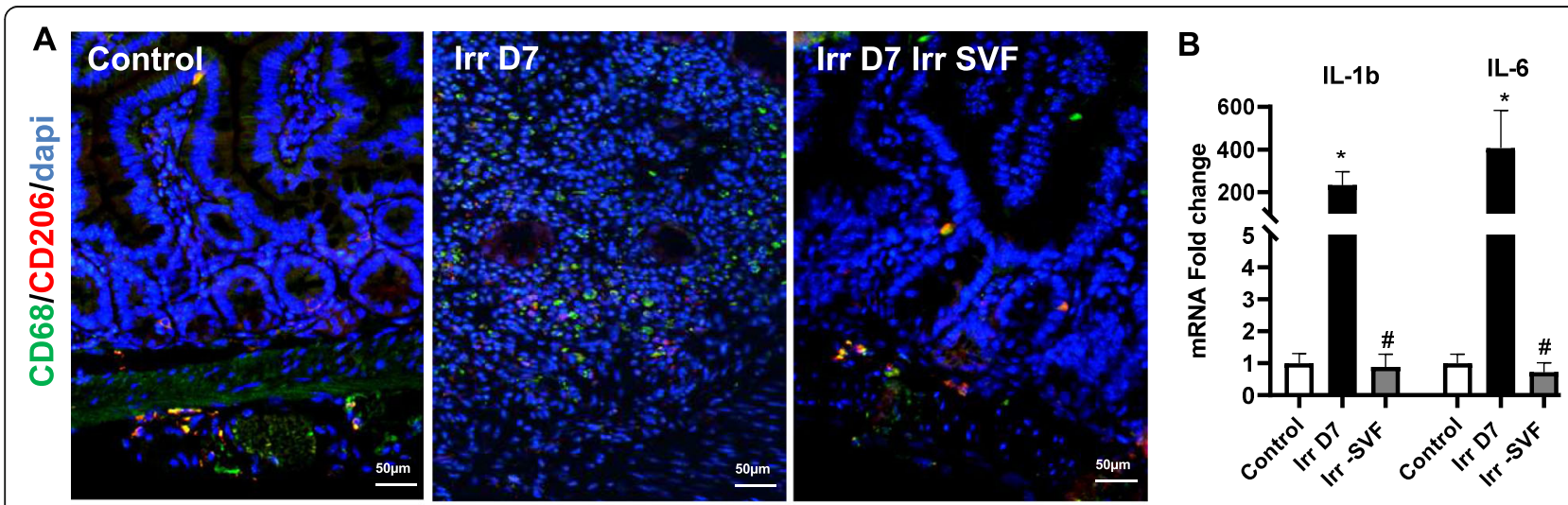

Fig. 7 SVF facilitated induction of M2 macrophages in the ileum and reduced radiation-induced inflammatory response. a IHC co-staining CD68 (green) and CD206 (red) in the ileum showing an increase of the co-staining CD68/CD206 related to M2 macrophage after SVF treatment. Dapi stained nuclei. $\mathbf{b}$ Real-time PCR analysis of IL-1 $\beta$ and IL-6. The results are expressed as means \pm SEM ( $n=8$ ). $p$ values were calculated by analysis of variance with Bonferroni correction; ${ }^{*} p<0.001$ compared with the control mice; $\# p<0.001$ compared with the irradiated mice 
treatment both stimulated the epithelial cell regeneration and restored the impermeability as indicated by ZO-1 and EpCam IHC and measurement of permeability. Moreover, SVF treatment leads to hyperproliferative $\mathrm{Ki}^{+} 7^{+}$areas, features typical of actively regenerating intestinal epithelium [34] combined with the restoration of the $\mathrm{Gp} 38^{+} \mathrm{CD} 34^{+}$mesenchymal cells associated to crypts, which plays a predominant role in the maintenance of ISCs pool [22, 25].

Under physiological conditions, ISCs LGR $5^{+}$located at the bottom of the crypts are responsible for the replenishment of intestinal epithelial cells. Using the genetic labelling and the tracing of distinct cell types, recent reports have indicated that $\mathrm{Lgr}^{+}$ISC are radiosensitive. At an abdominal dose of $10 \mathrm{~Gy}$, the surviving $\mathrm{Lgr}^{+}{ }^{+}$ISCs are still sufficient to sustain complete intestinal recovery 2 weeks after irradiation [35]; beyond this dose, the more widespread apoptosis of $\mathrm{Lgr}^{+}$ISCs induces a failure in the restoration of viability of the small intestine [36]. In our study, in order to visualise the ISC compartment, we used the co-location of CD24, more strongly expressed at the base of the crypt [23, 37, 38] and the lysozyme expressed by the Paneth cells that support the stem cell niche of the crypt [2]. We showed that irradiation caused a significant loss of ISC and Paneth cells. At day 7 after 18 Gy irradiation, the time and the dose where the modest surviving $\mathrm{Lgr}^{+}$ISCs could not dramatically support intestinal recovery, treatment with SVF restored the $\mathrm{CD}_{2} 4^{+}$lysozyme $^{-}$and Paneth cell populations, increased the proliferation of the TA compartment $\left(\mathrm{Ki}^{+} 7^{+} / \mathrm{CD} 24^{+}\right)$as well as the proliferation of Paneth cells $\left(\right.$ lysosyme ${ }^{+} / \mathrm{KI} 67^{+}$), whereas under normal homeostasis, Paneth cells do not express ISC or proliferative markers in vivo [39].

It has already been shown that Paneth cells can return to the proliferative state and differentiate into all types of epithelial cells after radiation injury. Schmitt et al. [40] have indeed shown that, in acute inflammation, Paneth cells de-differentiate into proliferating stem-like cells that are able to form 3D organoids ex vivo (in the absence of $\mathrm{LGR}^{+}$cells), whereas LGR $^{+}$cells alone cannot form organoids, and finally repopulate the epithelial wall in vivo [38]. In addition, a depletion of Paneth cells leads to a concomitant reduction of $\mathrm{Lgr}^{+}$ISCs [41]. In our work, SVF treatment was associated with a proliferation of Paneth cells as well as their number per crypt. Interestingly, this effect was also observed in the "upper crypt," which could suggest a process of dedifferentiation [25]. Thus, we observed the presence of a lysozyme ${ }^{+} /$ Muc2 $^{+}$population after treatment with SVF. These cells expressed Paneth and goblet biomarkers reflecting a bipotential progenitor of secretory cells, or intermediate cells [25]. In addition, mitochondrial impairment reduced stemness induced by loss of Paneth cell functionality and ISC differentiation. Specifically, HSP60 deficiency in ISC has been associated with complete loss of proliferation [26]. SVF treatment restored a mitochondrial function in the proliferation area which may have ensured the stemness.

Inflammatory cells such as monocytes/macrophages influence intestinal epithelium repair and generate dysfunctional PCs characterised by loss of lysozyme positive granules, concomitant to aberrant ISC phenotype such as observed in active ileal Crohn's disease [26, 42]. Intestinal mucosa macrophages are dependent on constant replenishment by classical blood monocytes [43] and the spleen produces a majority of monocyte subsets generating macrophages [28]. Tissue repair after inflammatory insult requires coordinated mobilisation of both subsets: Ly6 $C^{\text {high }}$ monocytes, which digest damaged tissue, but their persistence is deleterious and Ly6 $\mathrm{C}^{\text {low }}$ monocytes act on wound healing [44]. The spleen is the reservoir accommodating the demands of rapid-onset inflammation and we showed that the spleens from the irradiated mice were characterised by an accumulation of proinflammatory monocyte subset Ly6 $\mathrm{C}^{\text {high }} \mathrm{CCR} 2{ }^{\text {high }}$ phenotypes and a high potential of migration characterised in the spreading assay. In the spleens from the SVF-treated mice, although the pro-inflammatory monocytes level was not reduced, we inversely observed an increase in the level of anti-inflammatory monocytes Ly6C $\mathrm{C}^{\text {low }}$ $\mathrm{Cx} 3 \mathrm{cr} 1^{\text {high }}$, which can be matured in vitro in the antiinflammatory macrophage M2. Our results support the fact that SVF treatment is associated with antiinflammatory process both by repressing the proinflammatory cytokines and by shifting the macrophage polarity toward the M2 phenotype implicated in the inflammatory resolution phase and tissue regeneration [42]. More experiments are needed to understand the role of M2 macrophages in the ISC compartment after SVF treatment. Recently, it was shown that the depletion of macrophages resulted in decreased as well as crypt fission, $\operatorname{Lgr} 5^{+}$stem cell proliferation and Paneth cell numbers [45].

\section{Conclusion}

In this work, we have shown that treatment with SVF mitigates the GIS. This cell therapy product stimulates regeneration and intestinal repair targeting the stem cell compartment and provides an immunomodulatory response that enables the animals to survive at lethal doses.

\section{Abbreviations}

SVF: Stromal vascular fraction; GIS: Gastrointestinal syndrome; Gy: Gray; ISCs: Intestinal stem cells; EpCam: Epithelial cell adhesion molecule; IECS: Intestinal epithelial stem cells 


\section{Supplementary Information}

The online version contains supplementary material available at https://doi. org/10.1186/s13287-021-02373-y.

Additional file 1: Figure S1. Gating strategies utilized for analyzing sub-populations within the stromal vascular fraction of mice. a) ASC-like populations. Isotype controls are shown as blue histogram. b) Leucocytes populations.

Additional file 2: Table S1. Taqman primers and probes.

\section{Acknowledgements}

The authors thank the animal core facility GSEA from the IRSN.

\section{Authors' contributions}

L.B carried out the experimentation and analysed the data. C.S performed the SVF preparation and characterisation. C.D performed the SVF preparation and flow cytometry analysis. N.M, M.B, B.LG and F.M reviewed the manuscript. C.L performed the study design and experiments, analysed the data and wrote the manuscript. The authors read and approved the final manuscript.

\section{Funding}

This work was supported by a grant from EDF (Electricité de France) and ANR (AID/DGA, ASTRID).

\section{Availability of data and materials}

All relevant data and material to reproduce the findings are available in the manuscript.

\section{Declarations}

Ethics approval and consent to participate

All experiment procedures in this study were approved and performed in accordance with the guidelines of the Animal Ethics Committee from the French Ministry of Agriculture (EC Directive 2010/63/EU and French Decret 2013-118).

\section{Consent for publication}

Not applicable in this section.

\section{Competing interests}

The authors declare that they have no competing interests.

\section{Author details}

Institute of Radiological Protection and Nuclear Safety, Laboratory of Medical Radiobiology, Fontenay-aux-Roses, France. ${ }^{2}$ Electricité de France, Cap Ampère, Saint-Denis, France.

\section{Received: 1 April 2021 Accepted: 9 May 2021}

\section{Published online: 29 May 2021}

\section{References}

1. Barker N, van Es JH, Kuipers J, Kujala P, van den Born M, Cozijnsen M, et al. Identification of stem cells in small intestine and colon by marker gene Lgr5. Nature. 2007:449(7165):1003-7. https://doi.org/10.1038/nature06196.

2. Clevers HC, Bevins CL. Paneth cells: maestros of the small intestinal crypts. Annu Rev Physiol. 2013;75(1):289-311. https://doi.org/10.1146/annurevphysiol-030212-183744.

3. Potten CS. Stem cells in gastrointestinal epithelium: numbers, characteristics and death. Philos Trans R Soc Lond B Biol Sci. 1998:33:821-30.

4. Gunter-Smith PJ. Gamma radiation affects active electrolyte transport by rabbit ileum: basal Na and Cl transport. Am J Physiol. 1986;250(4 Pt 1):G540 5. https://doi.org/10.1152/ajpgi.1986.250.4.G540.

5. Krivokrysenko VI, Shakhov AN, Singh VK, Bone F, Kononov Y, Shyshynova I, et al. Identification of granulocyte colony-stimulating factor and interleukin6 as candidate biomarkers of CBLB502 efficacy as a medical radiation countermeasure. J Pharmacol Exp Ther. 2012;343(2):497-508. https://doi. org/10.1124/jpet.112.196071.

6. Krivokrysenko VI, Toshkov IA, Gleiberman AS, Krasnov P, Shyshynova I, Bespalov I, et al. The Toll-like receptor 5 agonist entolimod mitigates lethal acute radiation syndrome in non-human primates. Plos One. 2015;10(9): e0135388. https://doi.org/10.1371/journal.pone.0135388.

7. Saha S, Bhanja P, Kabarriti R, Liu L, Alfieri AA, Guha C. Bone marrow stromal cell transplantation mitigates radiation-induced gastrointestinal syndrome in mice. Plos One. 2011;6(9):e24072. https://doi.org/10.1371/journal.pone.0024072.

8. François S, Bensidhoum M, Mouiseddine M, Mazurier C, Allenet B, Semont A, et al. Local irradiation not only induces homing of human mesenchymal stem cells at exposed sites but promotes their widespread engraftment to multiple organs: a study of their quantitative distribution after irradiation damage. Stem Cells. 2006;24(4):1020-9. https://doi.org/10.1634/stemcells.2 005-0260.

9. Semont A, Mouiseddine M, Francois A, Demarquay C, Mathieu N, Chapel A, et al. Mesenchymal stem cells improve small intestinal integrity through regulation of endogenous epithelial cell homeostasis. Cell Death Differ. 2010;17(6):952-61. https://doi.org/10.1038/cdd.2009.187.

10. Semont A, Demarquay C, Bessout R, Durand C, Benderitter M, Mathieu N. Mesenchymal stem cell therapy stimulates endogenous host progenitor cells to improve colonic epithelial regeneration. Plos One. 2013;8(7):e70170. https://doi.org/10.1371/journal.pone.0070170.

11. Linard C, Busson E, Holler V, Strup-Perrot C, Lacave-Lapalun JV, Lhomme B, et al. Repeated autologous bone marrow-derived mesenchymal stem cell injections improve radiation-induced proctitis in pigs. Stem Cells Transl Med. 2013;2(11):916-27. https://doi.org/10.5966/sctm.2013-0030.

12. Dykstra JA, Facile T, Patrick RJ, Francis KR, Milanovich S, Weimer JM, Kota DJ. C Concise Review: Fat and furious: harnessing the full potential of adiposederived stromal vascular fraction. Stem Cells Transl Med. 2017;6:1096-1108, 4, doi: https://doi.org/10.1002/sctm.16-0337.

13. Han S, Sun HM, Hwang KC, Kim SW. Adipose-derived stromal vascular fraction cells: update on clinical utility and efficacy. Crit Rev Eukaryot Gene Expr. 2015;25(2):145-52. https://doi.org/10.1615/CritRevEukaryotGeneExpr.2 015013057.

14. Astori G, Vignati F, Bardelli S, Tubio M, Gola M, Albertini V, et al. "In vitro" and multicolor phenotypic characterization of cell subpopulations identified in fresh human adipose tissue stromal vascular fraction and in the derived mesenchymal stem cells. J Transl Med. 2007;5(1):55. https://doi.org/10.11 86/1479-5876-5-55.

15. Philandrianos C, Serrero M, Grimaud F, Magalon J, Visée C, Velier M, et al. First clinical case report of local microinjection of autologous fat and adipose-derived stromal vascular fraction for perianal fistula in Crohn's disease. Stem Cell Res Ther. 2018;9(1):4. https://doi.org/10.1186/s13287-0170736-6.

16. Gorin NC, Fliedner TM, Gourmelon P, Ganser A, Meineke V, Sirohi B, et al. Consensus conference on European preparedness for haematological and other medical management of mass radiation accidents. Ann Hematol. 2006:85(10):671-9. https://doi.org/10.1007/s00277-006-0153-x.

17. Bowles AC, Wise RM, Gerstein BY, Thomas RC, Ogelman R, Febbo I, et al. Immunomodulatory effects of adipose stromal vascular fraction cells promote alternative activation macrophages to repair tissue damage. Stem Cells. 2017:35(10):2198-207. https://doi.org/10.1002/stem.2689.

18. Withers HR, Elkind MM. Microcolony survival assay for cells of mouse intestinal mucosa exposed to radiation. Int J Radiat Biol Relat Stud Phys Chem Med. 1970;17(3):261-7. https://doi.org/10.1080/09553007014550291.

19. Terry NH, Travis EL. The influence of bone marrow depletion on intestinal radiation damage. Int J Radiat Oncol Biol Phys. 1989;17(3):569-73. https:// doi.org/10.1016/0360-3016(89)90108-9.

20. Dawson PA, Huxley S, Gardiner B, Tran T, McAuley JL, Grimmond S, et al Reduced mucin sulfonation and impaired intestinal barrier function in the hyposulfataemic NaS1 null mouse. Gut. 2009:58(7):910-9. https://doi.org/1 0.1136/gut.2007.147595

21. Schnell U, Cirulli V, Giepmans BN. EpCAM: structure and function in health and disease. Biochim Biophys Acta. 1828;2013:1989-2001.

22. Stzepourginski I, Nigro G, Jacob JM, Dulauroy S, Sansonetti PJ, Eberl G, et al. CD34+ mesenchymal cells are a major component of the intestinal stem cells niche at homeostasis and after injury. Proc Natl Acad Sci U S A. 2017; 114(4):E506-13. https://doi.org/10.1073/pnas.1620059114.

23. von Furstenberg RJ, Gulati AS, Baxi A, Doherty JM, Stappenbeck TS, Gracz $A D$, et al. Sorting mouse jejunal epithelial cells with CD24 yields a population with characteristics of intestinal stem cells. Am J Physiol Gastrointest Liver Physiol. 2011;300(3):G409-17. https://doi.org/10.1152/ajpgi. 00453.2010 
24. Langlands AJ, Almet AA, Appleton PL, Newton IP, Osborne JM, Näthke IS. Paneth cell-rich regions separated by a cluster of Lgr5+ cells initiate crypt fission in the intestinal stem cell niche. Plos Biol. 2016;14(6):e1002491. https://doi.org/10.1371/journal.pbio.1002491.

25. Smith NR, Davies PS, Levin TG, Gallagher AC, Keene DR, Sengupta SK, et al Cell adhesion molecule CD166/ALCAM functions within the crypt to orchestrate murine intestinal stem cell homeostasis. Cell Mol Gastroenterol Hepatol. 2017;3(3):389-409. https://doi.org/10.1016/j.jcmgh.2016.12.010.

26. Khaloian S, Rath E, Hammoudi N, Gleisinger E, Blutke A, Giesbertz P, et al. Mitochondrial impairment drives intestinal stem cell transition into dysfunctional Paneth cells predicting Crohn's disease recurrence. Gut. 2020; 69(11):1939-51. https://doi.org/10.1136/gutjnl-2019-319514.

27. Swirski FK, Nahrendorf M, Etzrodt M, Wildgruber M, Cortez-Retamozo V, Panizzi $P$, et al. Identification of splenic reservoir monocytes and their deployment to inflammatory sites. Science. 2009;325(5940):612-6. https:// doi.org/10.1126/science.1175202.

28. Hettinger J, Richards DM, Hansson J, Barra MM, Joschko AC, Krijgsveld J, et al. Origin of monocytes and macrophages in a committed progenitor. Nat Immunol. 2013;14(8):821-30. https://doi.org/10.1038/ni.2638.

29. Miteva K, Pappritz K, El-Shafeey M, Dong F, Ringe J, Tschöpe C, et al. Mesenchymal stromal cells modulate monocytes trafficking in Coxsackievirus B3-induced myocarditis. Stem Cells Transl Med. 2017;6(4): 1249-61. https://doi.org/10.1002/sctm.16-0353.

30. Linard C, Brachet M, L'homme B, Strup-Perrot C, Busson E, Bonneau M, et al. Long-term effectiveness of local BM-MSCs for skeletal muscle regeneration: a proof of concept obtained on a pig model of severe radiation burn. Stem Cell Res Ther. 2018;9(1):299. https://doi.org/10.1186/s13287-018-1051-6.

31. Chang P, Qu Y, Liu Y, Cui S, Zhu D, Wang H, et al. Multitherapeutic effects of human adipose-derived mesenchymal stem cells on radiation-induced intestinal injury. Cell Death Dis. 2013;4(6):e685. https://doi.org/10.1038/ cddis.2013.178.

32. Francois A, Milliat F, Guipaud O, Benderitter M. Inflammation and immunity in radiation damage to the gut mucosa. Biomed Res Int. 2013;2013:123241.

33. Sun $Y$, Chen S, Zhang $X$, Pei M. Significance of cellular cross-talk in stromal vascular fraction of adipose tissue in neovascularization. Arterioscler Thromb Vasc Biol. 2019;39(6):1034-44. https://doi.org/10.1161/ATVBAHA.119.312425.

34. Metcalfe C, Kljavin NM, Ybarra R, de Sauvage FJ. Lgr5+ stem cells are indispensable for radiation-induced intestinal regeneration. Cell Stem Cell. 2014;14(2):149-59. https://doi.org/10.1016/j.stem.2013.11.008.

35. Sato T, Sase M, Ishikawa S, Kajita M, Asano J, Sato T, et al. Characterization of radioresistant epithelial stem cell heterogeneity in the damaged mouse intestine. Sci Rep. 2020;10(1):8308. https://doi.org/10.1038/s41598-020-64 987-1.

36. Hua G, Thin TH, Feldman R, Haimovitz-Friedman A, Clevers H, Fuks Z, et al. Crypt base columnar stem cells in small intestines of mice are radioresistant. Gastroenterology. 2012;143(5):1266-76. https://doi.org/10.1053/j.gastro.2012. 07.106.

37. Wang F, Scoville D, He XC, Mahe MM, Box A, Perry JM, et al. Isolation and characterization of intestinal stem cells based on surface marker combinations and colony-formation assay. Gastroenterology. 2013;145(2): 383-95. https://doi.org/10.1053/j.gastro.2013.04.050.

38. Yu S, Tong K, Zhao Y, Balasubramanian I, Yap GS, Ferraris RP, et al. Paneth cell multipotency induced by Notch activation following injury. Cell Stem Cell. 2018;23(1):46-59. https://doi.org/10.1016/j.stem.2018.05.002.

39. Basak O, van de Born M, Korving J, Beumer J, van der Elst $\mathrm{S}$, van Es JH, et al. Mapping early fate determination in Lgr5+ crypt stem cells using a novel Ki67-RFP allele. EMBO J. 2014;33(18):2057-68. https://doi.org/10.15252/ embj.201488017.

40. Schmitt M, Schewe M, Sacchetti A, Feijtel D, van de Geer WS, Teeuwssen M, et al. Paneth cells respond to inflammation and contribute to tissue regeneration by acquiring stem-like features through SCF/c-Kit signaling. Cell Rep. 2018;24(9):2312-28. https://doi.org/10.1016/j.celrep.2018.07.085.

41. Sato T, van Es JH, Snippert HJ, Stange DE, Vries RG, van den Born M, et al. Paneth cells constitute the niche for Lgr5 stem cells in intestinal crypts. Nature. 2011;469(7330):415-8. https://doi.org/10.1038/nature09637.

42. Saha S, Aranda E, Hayakawa Y, Bhanja P, Atay S, Brodin NP, et al. Macrophage-derived extracellular vesicle-packaged WNTs rescue intestinal stem cells and enhance survival after radiation injury. Nat Commun. 2016; 7(1):13096. https://doi.org/10.1038/ncomms13096.

43. Bain CC, Bravo-Blas A, Scott CL, Perdiguero EG, Geissmann F, Henri S, et al. Constant replenishment from circulating monocytes maintains the macrophage pool in the intestine of adult mice. Nat Immunol. 2014;15(10): 929-37. https://doi.org/10.1038/ni.2967.

44. Yang J, Zhang L, Yu C, Yang XF, Wang H. Monocyte and macrophage differentiation: circulation inflammatory monocyte as biomarker for inflammatory diseases. Biomark Res. 2014;2(1):1-9. https://doi.org/10.1186/2 050-7771-2-1.

45. Riehl TE, Alvarado D, Ee X, Ciorba MA, Stenson WF. Hyaluronic acid promotes Lgr5+ stem cell proliferation and crypt fission through TLR4 and PGE 2 transactivation of EGFR. Am J Physiol Gastrointest Liver Physiol. 2020; 319(1):G63-73. https://doi.org/10.1152/ajpgi.00242.2019.

\section{Publisher's Note}

Springer Nature remains neutral with regard to jurisdictional claims in published maps and institutional affiliations.

\section{Ready to submit your research? Choose BMC and benefit from:}

- fast, convenient online submission

- thorough peer review by experienced researchers in your field

- rapid publication on acceptance

- support for research data, including large and complex data types

- gold Open Access which fosters wider collaboration and increased citations

- maximum visibility for your research: over $100 \mathrm{M}$ website views per year

At BMC, research is always in progress.

Learn more biomedcentral.com/submissions 